\title{
Anatomic changes due to interspecific grafting in cassava (Manihot esculenta)
}

\author{
N. Bomfim, D.G. Ribeiro and N.M.A. Nassar \\ Departamento de Botânica, Universidade de Brasília, Brasília, DF, Brasil \\ Corresponding author: N.M.A. Nassar \\ E-mail: nagnassa@rudah.com.br
}

Genet. Mol. Res. 10 (2): 1011-1021 (2011)

Received November 4, 2010

Accepted December 23, 2010

Published May 31, 2011

DOI 10.4238/vol10-2gmr1138

\begin{abstract}
Cassava rootstocks of varieties UnB 201 and UnB 122 grafted with scions of Manihot fortalezensis were prepared for anatomic study. The roots were cut, stained with safranin and alcian blue, and examined microscopically, comparing them with sections taken from ungrafted roots. There was a significant decrease in number of pericyclic fibers, vascular vessels and tyloses in rootstocks. They exhibited significant larger vessels. These changes in anatomic structure are a consequence of genetic effects caused by transference of genetic material from scion to rootstock. The same ungrafted species was compared. This is the first report on anatomic changes due to grafting in cassava.
\end{abstract}

Key words: Manihot fortalezensis; Root secondary growth; Cassava root anatomy; Anatomic change; Manihot anatomy 


\section{INTRODUCTION}

Some researchers have claimed that genetic changes may arise due to grafting, but this idea was strongly rejected by Eastern scientists for many decades (Ohta and Chuong, 1975; Taller et al., 1999; Liu, 2006). Genetic effects of the scion on rootstock may lead to tremendous consequences in the breeding of woody plants, where grafting is frequently used. The latest report by Stegemann and Bock (2009) pointed out the possibility of DNA transfer from rootstock to scion and vice versa. Since cassava in traditional horticultural applications exhibits a notable enlargement of rootstock roots, this prompted us to determine if there are anatomic alterations due to these presumed translocations. Pragmatically speaking, genetic alterations have been proven to be an invaluable instrument in plant breeding and may open a new era in this science. Thus, many economic characters may be transferred within a very short period compared to classical methods. It may be possible, for example, to transfer these characters by simple grafting, which would take tens of generations to accomplish by traditional plant breeding methods.

The influence of the graft on the rootstock with respect to leaf area, gas exchange, aerial biomass, and net assimilation rate has been studied in cassava (Ramanujam and Ghosh, 1990; Pellet and El-Sharkawy, 1994), but there has been no study of the effects on anatomic structure. Anatomic studies of grafted cassava serve to evaluate grafting potential in cassava breeding. This study aimed to assess grafting effects of a wild Manihot species on cassava rootstocks.

\section{MATERIAL AND METHODS}

Manihot fortalezensis is a tall shrub of ca. $15 \mathrm{~m}$, with slender stem (Figure 1A), with leaves with 5-7 lobes (Figure 1B); it is native to Ceará State, Brazil, and maintained at the Living Collection, Universidade de Brasília. Cassava variety UnB 122 is a shrub (Figure 1C), $2 \mathrm{~m}$ high, with leaves with 3-5 lobes (Figure 1D) and rarely one lobe; it was selected from cassava $\mathrm{x}$ M. anomala hybrid progeny. Cassava variety UnB 201 is a shrub $2.5 \mathrm{~m}$ high (Figure $1 \mathrm{E}$ ), with leaves with 5-7 lobes (Figure 1D), is an indigenous variety and was collected from Amapá State, Brazil, where it is popularly cultivated and consumed.

Root anatomy of $M$. fortalezensis Nassar et al. and M. esculenta Crantz (Cassava) ungrafted was studied and compared to cassava rootstocks. M. fortalezensis was used as scion, and the 2 varieties of cassava UnB 201 and UnB 122 were used as stock. Splice grafts were applied in these grafts as cutting onto cutting. Roots were collected for study after 11 months of planting.

Roots with 0.3 to $1.3 \mathrm{~cm}$ in diameter were collected and fixed in 70\% FAA (Johansen, 1940) for a period of $24 \mathrm{~h}$ and preserved in $70 \%$ ethanol. Transverse and longitudinal sections were made by free-hand cuttings on a microtome, and the sections were cleared in $20 \%$ sodium hypochlorite (Kraus and Arduin, 1997) and stained with 1\% safranin and 1\% aqueous alcian blue (Luque et al., 1996). The stained sections were then dehydrated in an ethanol series, cleared in butyl acetate and mounted in synthetic resin (Paiva et al., 2006).

Histochemical tests were performed to determine druse composition, starch, suberin, latex, and lignin. Sections were subjected to $10 \%$ sulfuric acid and glacial acetic acid to determine the chemical composition of the crystals (MacLean and Ivemey-Cook, 1952). To highlight starch, sections were treated with Lugol's solution (Langeron, 1949 apud Kraus and Arduin, 1997). Treatment with Sudan III and IV was used to detect suberin and latex (Sass, 1951). Lignin was detected by the use of acidified phloroglucinol (Kraus and Arduin, 1997). 


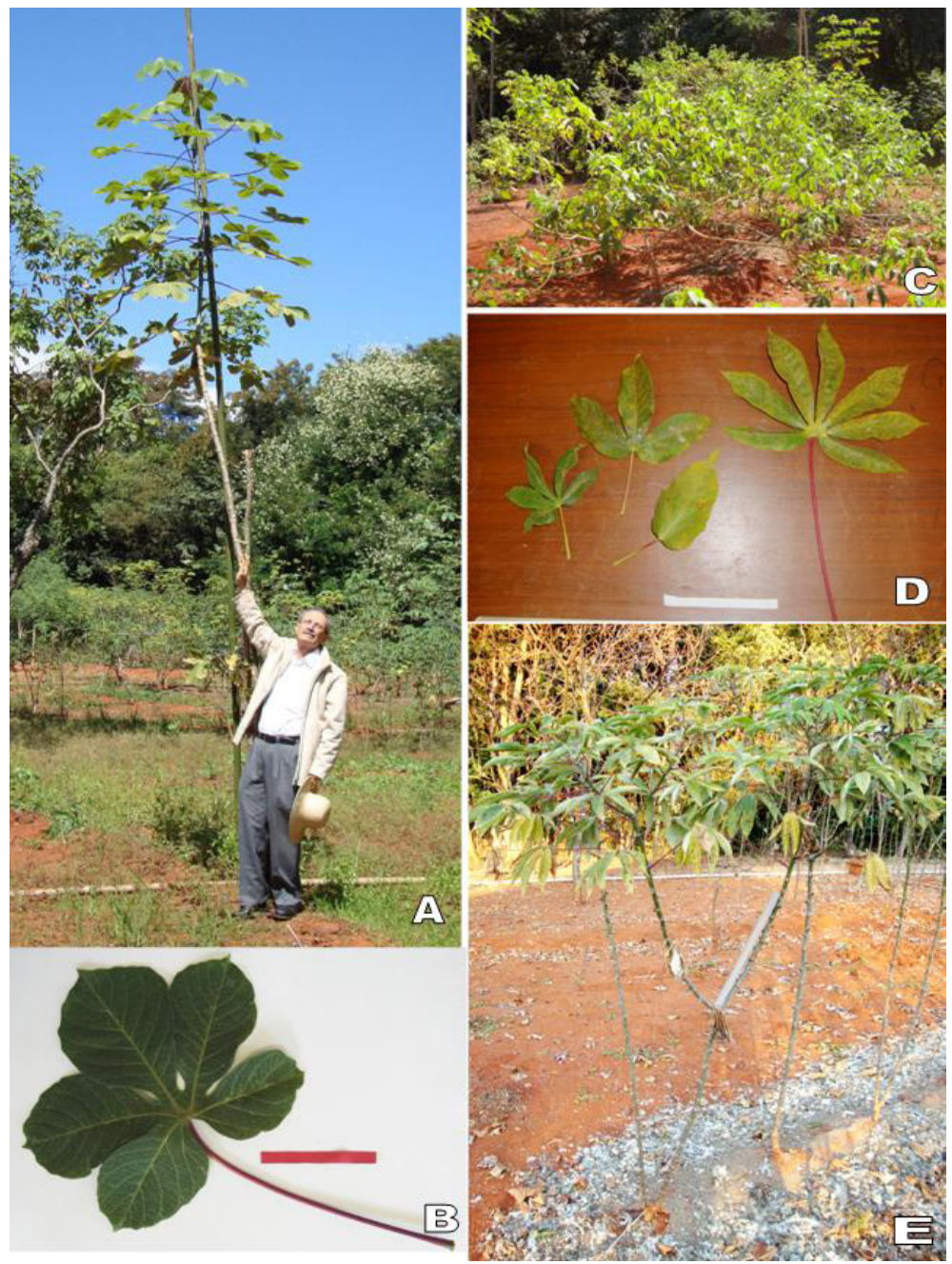

Figure 1. A. Manihot fortalezensis. High shrub (ca. 5 m). B. M. fortalezensis: 5-lobed leaf. C. Cassava variety UnB 122, branched shrub (ca. $1.5 \mathrm{~m}$ ). D. Leaves of cassava variety UnB 122: 1-, 3- and 5-lobed leaves and leaf of cassava variety UnB 201: 7-lobed leaf. E. Cassava variety UnB 201. Erect shrub (ca. $1.5 \mathrm{~m}$ ). Bar: $10 \mathrm{~cm}$. Ruler: $30 \mathrm{~cm}$.

Photomicrographs were taken using an Axioskop Zeiss photomicroscope coupled to a Motic camera and Motic Images Vision 2.0.

The diameters and number of vessels were determined according to Richter and Dallwitz (2009) in Image-Pro Plus version 4.5 (Media Cybernetics, Silver Spring, MD, USA).

Estimation of total conduit area was based on the average diameter and vessel frequency. To determine differences between sizes, frequencies and areas of vessels, analysis of variance (ANOVA) was applied considering the Duncan multiple range test to be $95 \%$ probability.

Observations were made regarding the vegetative and reproductive growth of the plants studied. The height and period of flowering were noted. 


\section{RESULTS}

\section{Root description}

The roots studied were in secondary growth, 3-5 $\mathrm{mm}$ in diameter and not tuberized. All roots showed transverse sections with circular shape, and $M$. fortalezensis also showed oblong shape. All species studied had stratified periderm, broken at some points, with 10 to 73 layers of tabular phellem cells lignified with thin walls (Figure 2A, B, C and Figure 3A, B, C), usually with narrow and some detached outer layers. Tabular phellogen cells followed immediately by up to three layers of parenchyma cells were observed. These cells were large, isodiametric to oblong cells with calcium oxalate druses. In roots with cortex with more than $8 \mathrm{~mm}, 10$ layers were noted in some regions of M. fortalezensis and in front of lateral roots of the cassava variety 122 .

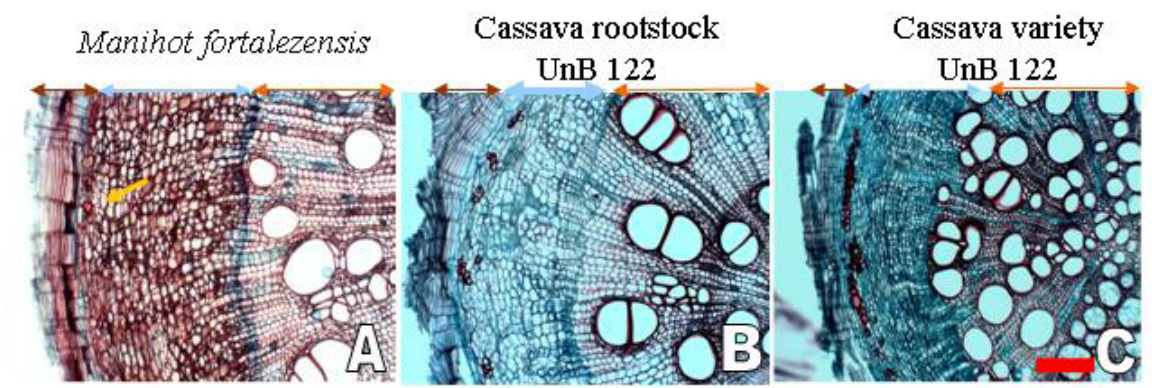

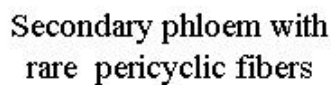
rare pericyclic fibers
Secondary phloem with Secondary phloem with pericyclic fibers in arcs pericyclic fibers in arcs with with up to 9 cells up to 10 cells near one another

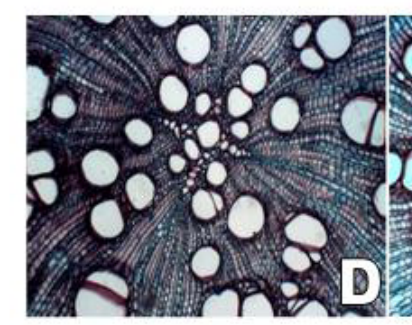

Tyloses with starch are frequent
Fewer vessels and similar diameter as in M. fortalezensis

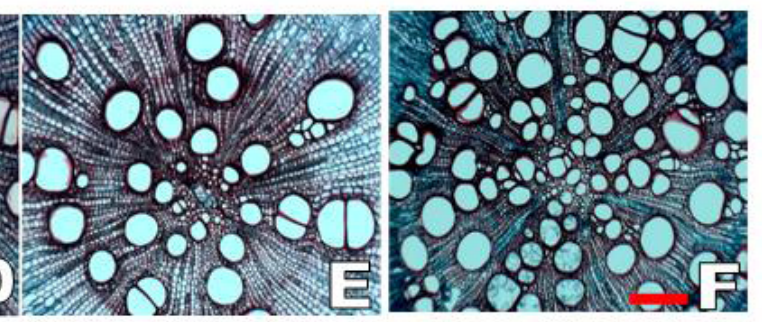

Tyloses with starch are frequent

Tyloses are absent

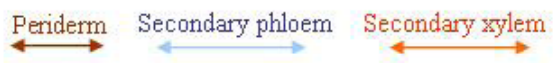

Figure 2. A. Manihot fortalezensis. Rare pericyclic fibers (arrow). B. Cassava rootstock UnB 122 grafted. Pericyclic fibers in small arcs. C. Cassava variety UnB 122. Pericyclic fibers in bigger arcs near one another. $D, E$, $F$, Secondary xylem. D. $M$. fortalezensis. E. Cassava rootstock UnB 122. Fewer vessels with similar diameter as in M. fortalezensis and tyloses absent. F. Cassava variety UnB 122 with frequent tyloses. Bar: $300 \mu \mathrm{m}$. 

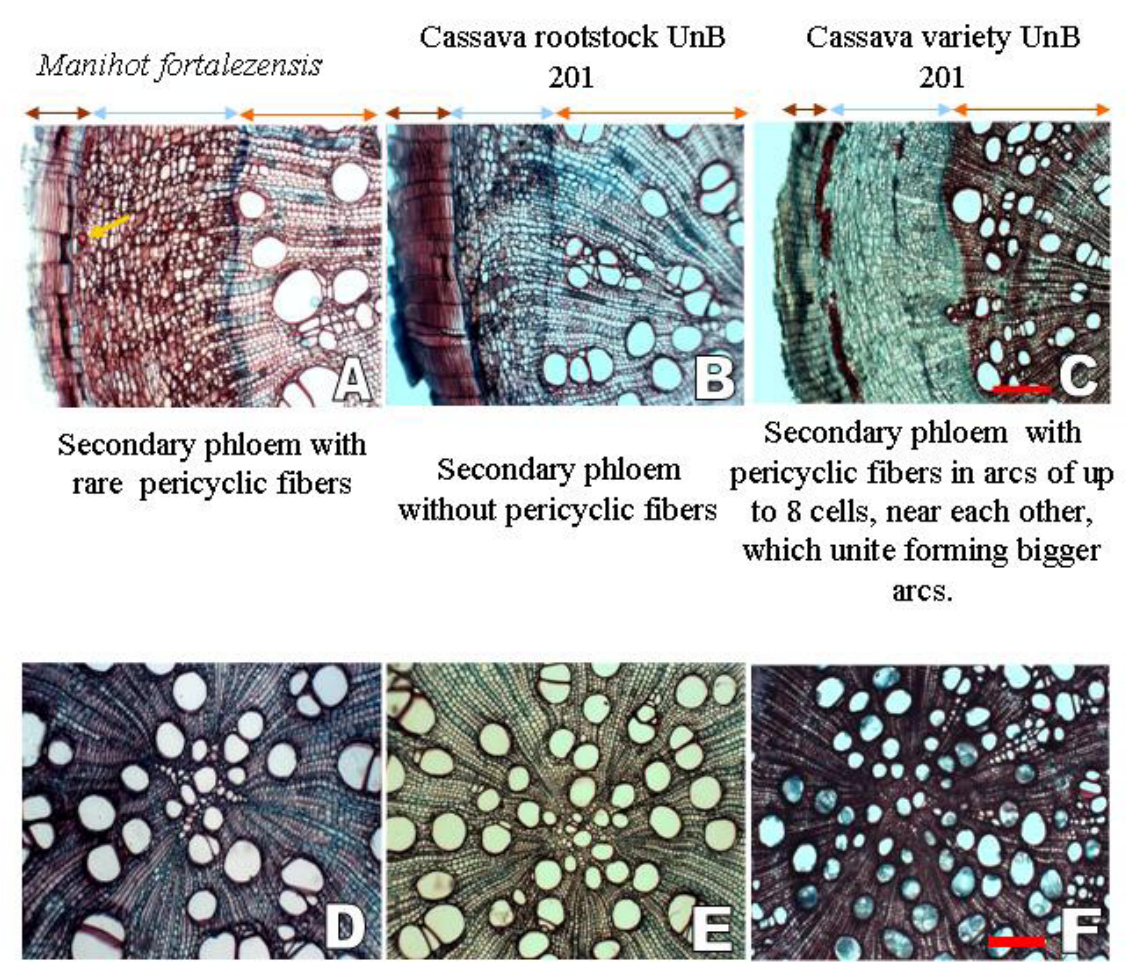

Tyloses with starch are frequent
Larger and fewer vessels than in cassava variety UnB 201
Tyloses with starch are very frequent

Tyloses are rare

$\stackrel{\text { Periderm Secondary phloem Secondary zylem }}{\longleftrightarrow}$

Figure 3. A. Manihot fortalezensis. Rare pericyclic fibers (arrow). B. Cassava rootstock UnB 201. Pericyclic fibers are absent. C. Cassava variety UnB 201. Great quantity of pericyclic fibers. $D, E, F$, Secondary xylem. D. $M$. fortalezensis. E. Cassava rootstock UnB 201. Larger and fewer vessels than in cassava variety UnB 201. Tyloses are rare. F. Cassava variety UnB 201. Tyloses with starch are very frequent. Bar: $300 \mu \mathrm{m}$.

Only in ungrafted plants of $M$. fortalezensis and both varieties of $M$. esculenta, were there circular to polygonal with 3-5 sides of pericyclic fibers. There were variable sizes and thicknesses of lignified walls in the same root. In M. fortalezensis, pericyclic fibers were rare (Figure 2A or Figure $3 \mathrm{~A}$ ), but near to injury and in regions with 10 layers of parenchyma cortex, fibers were arranged in groups of 5-14 cells and in greater quantity. The cassava varieties UnB 122 and UnB 201 showed pericyclic fibers arranged in semi-circles close to each other, formed by up to 10 cells (Figures $2 \mathrm{C}$ and $3 \mathrm{C}$ ). These cells joined together forming large semi-circles. In cassava rootstocks, pericyclic fibers were in smaller amounts in rootstock UnB 122, where they were arranged in semi-circles of up to 9 cells (Figure 2B) and absent in rootstock UnB 201 (Figure 3B).

All species studied showed primary and secondary phloem formed by sieve tubeelements with one or two companion cells, and radial parenchyma with starch and laticifers. There were 
remnants of primary phloem with parenchyma cells near the periphery of the root. In secondary phloem the inner layers showed sieve tubes and companion cells in larger numbers. Sieve plates were composite (Figure 4A). In the phloem parenchyma, cells were isodiametric and oblong with variable amounts of starch and calcium oxalate druses. At dilated rays some cells were 2-3 times larger than adjacent ones, which was frequent in M. fortalezensis. The axial parenchyma showed isodiametric cells with less starch than the radial. In all roots, they were noted as secondary phloem occupying a relatively large proportion of the root when compared to the xylem. The species studied showed articulated and branched laticifers, united by the dissolution of the walls forming channels (Figure 4B). These cells in transverse section were polygonal to isodiametric, arranged in rows of up to 12 cells (Figure 4C) with slightly thickened walls. Laticifers were arranged in parallel concentric and discontinuous rows. In M. fortalezensis and cassava variety UnB 201, up to 8 rows of laticifers were noted, while cassava variety UnB 122 and rootstock UnB 201 showed up to 5 rows and rootstock UnB 122 showed 3 rows of these.

In all species, secondary xylem showed vessel elements, parenchyma cells with starch, fibers libriforms, and gelatinous fibers. Vessel elements were present twinning and solitary with variable size. The pattern of wall thickening varied from bordered pitting to reticulate and scalariform. The 3 types were noted in the same section (Figure 4D). Perforation plates were simple. The vessel diameter and frequency was classified according to Richter and Dallwitz (2009). In all species, vessels belonged to the medium size class (size between 50 and $100 \mu \mathrm{m}$ ) and in relation to vessel number per $\mathrm{mm}^{2}$, they are classified into moderately frequent class (between 20 and 40 vessels per $\mathrm{mm}^{2}$ ), except for ungrafted varieties, UnB 201 and UnB 122, which belong to the frequent class (between 40 and 100 vessels per $\mathrm{mm}^{2}$ ). The mean diameter and mean frequency of vessels and total conduit area estimated per $\mathrm{mm}^{2}$ are shown in Table 1. Secondary xylem of M. fortalezensis, cassava varieties and cassava rootstock are compared in Figure 2D, E and F (where rootstock UnB 122 is compared) and in Figure 3D, E and F (where rootstock UnB 201 is compared). Only in cassava rootstocks was there a rare presence of tyloses with starch in the vessels.

All species showed xylem parenchyma ray cells with a polygonal shape with 4-6 sides, smaller in size than those found in the phloem, fully occupied by starch grains. All roots showed large amounts of libriform fibers, and walls with little variation in thickness. All roots also showed gelatinous fibers in the xylem. In M. fortalezensis (Figure 4E), cassava variety and rootstock UnB 201, there were more gelatinous fibers than in cassava variety and rootstock UnB 122. M. fortalezensis showed some regions formed only by parenchyma rich in starch that was very pronounced, compared to the cassava varieties (Figure 4F).

\section{Anatomic differences in root anatomy due to grafting}

Cassava rootstocks differ from ungrafted cassava varieties in relation to the quantity of pericyclic fibers, and diameter, frequency and content of vessels. Both rootstocks showed fewer pericyclic fibers (Figure 2A, B, C and Figure 3A, B, C) and fewer vessels (Table 1; Figures 2E and 3E). Furthermore, cassava rootstock UnB 201 showed larger vessels than cassava variety UnB 201. However, cassava rootstock UnB 122 showed similar vessel diameters and a much lower vessel frequency compared to M. fortalezensis and cassava varieties (Table 1; Figures 2 and 3). 


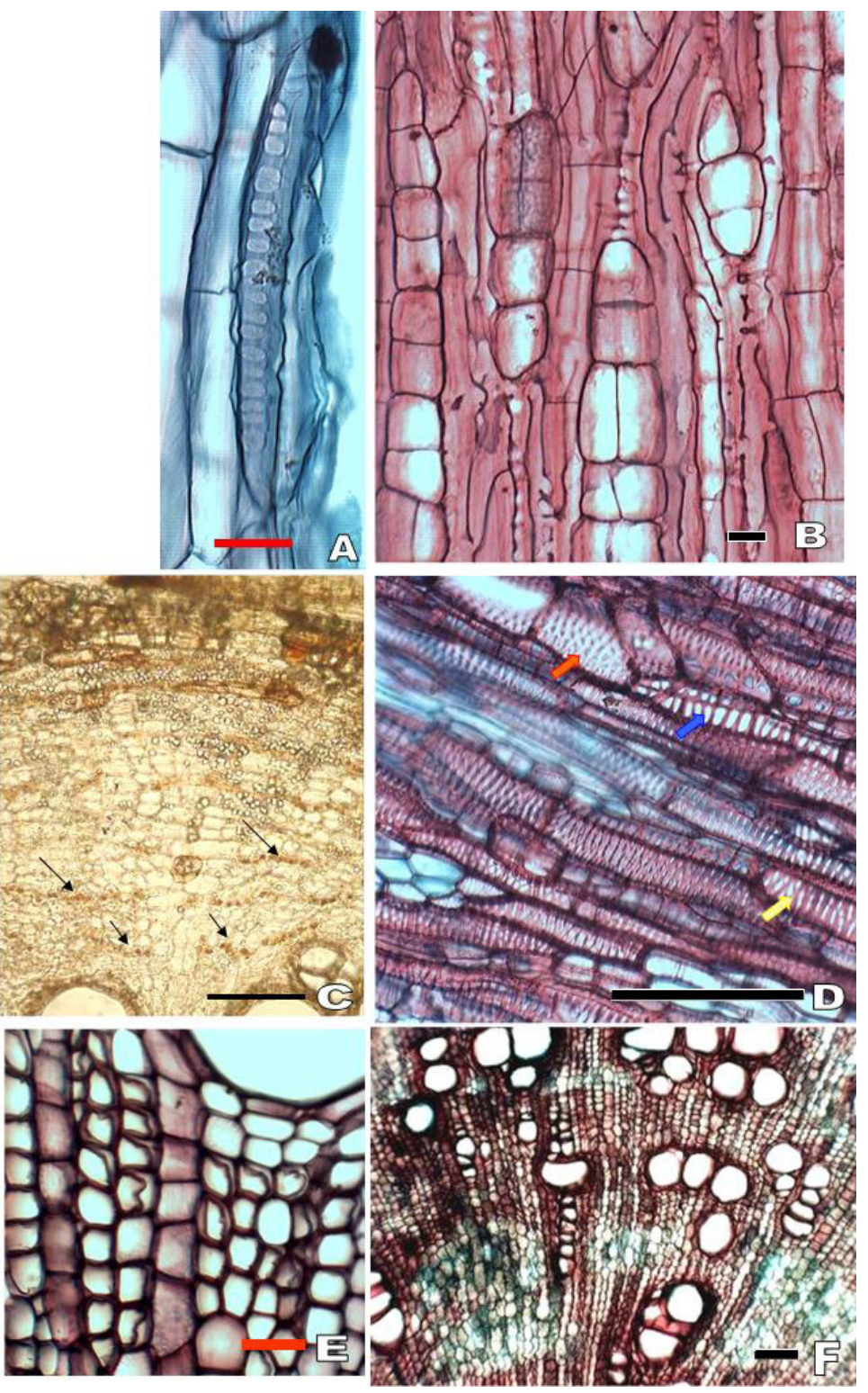

Figure 4. A. Sieve plate composite. B. Laticifers articulated and branched forming channels (longitudinal view). C. Laticifers (arrows) (transverse view). D. Three patterns of wall thickening: bordered pitting (red arrow) to reticulate (yellow arrow) and scalariform (blue arrow). E. Gelatinous fibers (Manihot fortalezensis). F. Parenchyma rich in starch in the lignified xylem (M. fortalezensis). Black bar: $150 \mu \mathrm{m}$. Red bar: $30 \mu \mathrm{m}$.

\section{Vegetative and reproductive growth}

In the grafted plants, both rootstock and scion sprouted. At 18 months, the rootstocks were compared in terms of height and root formation. The rootstock UnB 201 produced more 
Table 1. Quantitative characteristics of xylem vessels of grafted and ungrafted cassavas and Manihot fortalezensis.

\begin{tabular}{lccc}
\hline Species & $\begin{array}{c}\text { Mean xylem } \\
\text { vessel diameter }(\mu \mathrm{m})\end{array}$ & $\begin{array}{c}\text { Mean frequency } \\
\left(\text { number of vessel } / \mathrm{mm}^{2}\right)\end{array}$ & $\begin{array}{c}\text { Total estimated } \\
\text { conduit area/ } \mathrm{mm}^{2}\end{array}$ \\
\hline M. fortalezensis & $86.82 \pm 34.81^{\mathrm{a}}$ & $34.16 \pm 14.09^{\mathrm{b}}$ & $0.204 \pm 0.029^{\mathrm{c}}$ \\
Cassava variety UnB 201 & $69.71 \pm 22.83^{\mathrm{b}}$ & $50.83 \pm 5.74^{\mathrm{a}}$ & $0.2 \pm 0.028^{\mathrm{d}}$ \\
Cassava variety UnB 122 & $92.43 \pm 37.28^{\mathrm{a}}$ & $43.61 \pm 15.58^{\mathrm{a}}$ & $0.294 \pm 0.071^{\mathrm{a}}$ \\
Cassava rootstock UnB 201 & $92.17 \pm 37.94^{\mathrm{a}}$ & $33.05 \pm 2.453^{\mathrm{c}}$ & $0.223 \pm 0.038^{\mathrm{b}}$ \\
Cassava rootstock UnB 122 & $85.67 \pm 20.23^{\mathrm{a}}$ & $22.22 \pm 2.721^{\mathrm{d}}$ & $0.129 \pm 0.009^{\mathrm{c}}$ \\
\hline
\end{tabular}

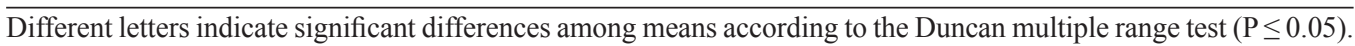

roots than the rootstock UnB 122, but grew less and did not produce flowers. On the other hand, the rootstock UnB 122 produced longer and narrower roots, grew more, and bloomed more heavily and early (Figure 5 ). The scion $M$. fortalezensis grew more on rootstock UnB 122 than on rootstock UnB 201. The scion (M. fortalezensis) on either rootstock did not bloom.

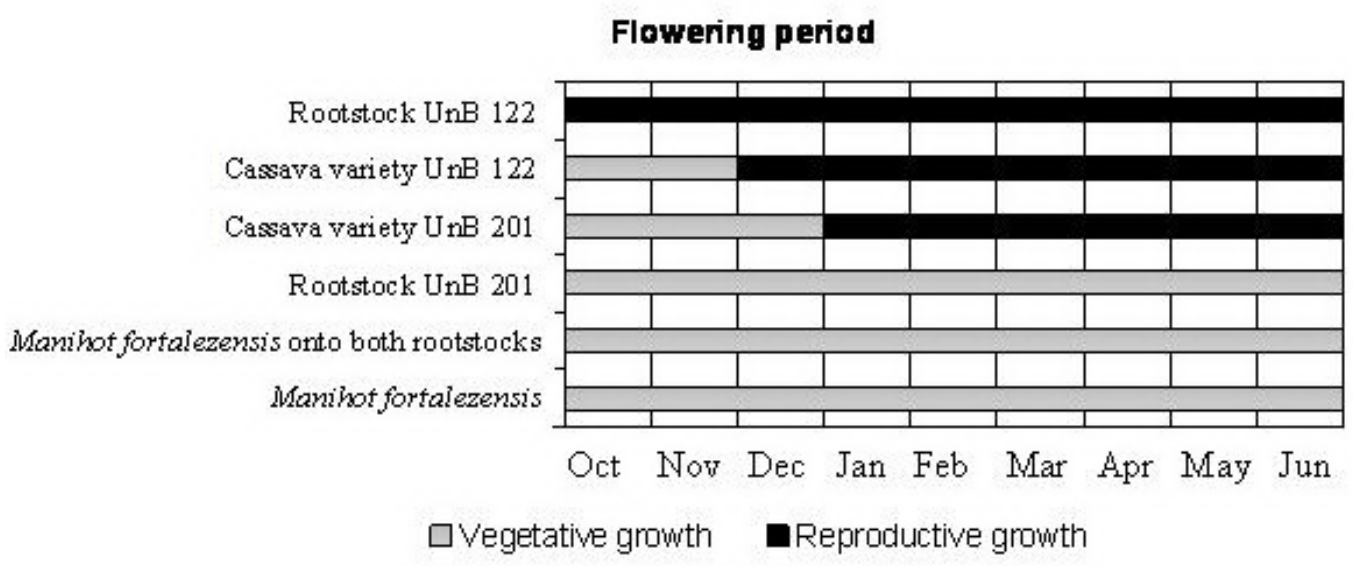

Figure 5. Flowering period of grafted and ungrafted cassava varieties and Manihot fortalezensis.

\section{DISCUSSION}

There are few studies on the probable genetic effects of grafting in cassava, almost none. The only one on cassava considered the phenomena from a certain viewpoint, which examined the effects of different scions on leaf area and root sink capacity (Brujin and Dharmaputra, 1974; Pellet and El-Sharkawy, 1994; Nassar, 1981, 2002). However, no mention was made of genetic effects.

In this study, changes in pericyclic fibers and xylem vessels of cassava rootstock were observed. These differences seem to be associated with the genetic interaction between scion and stock, because cassava rootstocks showed characteristics similar to those of $M$. fortalezensis (scion). Cassava rootstock UnB 201 showed similar diameter vessels as in the scion, while rootstock UnB 122 showed the lowest frequency of vessels. This was probably also influenced by the scion, which has fewer vessels than either cassava variety (Table 1). Since germ cells and somatic cells of juvenile plants can be changed by genes from older 
or mature plants (Liu, 2006; Stegemann and Bock, 2009), and the roots grew after grafting, all growth may be a result of the interaction between grafts. These results suggest that the anatomic differences found were due to the genetic action of the scion M. fortalezensis on cassava rootstock.

These possible alterations may result in a better vascular activity and in an increase in root production because the occurrence of larger vessels would improve water supply, since larger cross-sectional area of vessels may facilitate the transport of greater volumes of water per unit time (Fassio et al., 2009). A better water supply supports greater growth as well as being associated with vigor and flowering precocity (Solari et al., 2006; Mitani et al., 2008). Our results are in accordance with these reports because rootstock UnB 201 showed larger roots and less aerial growth. Cassava rootstock UnB 122 showed flowering precocity, despite fewer tuberous roots. This was expected, since there was a constant balance between aerial growth and root growth, as well as vegetative and reproductive growth. These results suggest that rootstock with narrow vessels produces more tuberous roots, when grafted and ungrafted cassavas are compared. Furthermore, the greater production of roots on rootstock UnB 201 than in rootstock UnB 122 confirms the reports of Pellet and El-Sharkawy (1994) and Nassar (2007), noting that in order to obtain good production it is essential to have an appropriate combination of scion and rootstock.

The other differences observed was in frequency and content of vessels and quantity of pericyclic fibers, which may be a consequence of larger vessels in rootstocks. The lower frequency of vessels is probably a result of a redirection in the relationship between vessel frequency and vessel area to reach scion demand (M. fortalezensis). However, some common interruptions at the graft junction can also reduce vessel frequency, because they reduce the transport of carbohydrates and hormones, such as auxin, which is required to cell differentiation (Schmid and Feucht, 1981; Hussein and MacFarland, 1994).

The other possible consequence of larger vessels is vessel content, because tylose formation increases under water deficit conditions (Rickard and Gahan, 1983), and the occurrence of fewer tyloses represents a better sap flow in xylem.

Water deficit conditions also increase lignin deposition (Fan et al., 2006; Yoshimura et al., 2008), which occurs in fibers and decrease if water supply improves. Therefore, it may help to understand the fewer pericyclic fibers in cassava rootstocks. This lower quantity of pericyclic fibers seemed to be a metabolism toward primary metabolites instead of secondary metabolites, such as lignin, because a greater quantity of roots was observed in cassava rootstock UnB 201 and flower precocity in cassava rootstock $\mathrm{UnB} 122$, compared to ungrafted cassavas and either process require a great amount of carbohydrates. This association was also noting in Kiwi rootstock, which showed fewer fibers in more flowering plants (Wang et al., 1994). Furthermore, less fibers may mean greater growth of roots, because lignin may stiffen cell walls and reduce growth (Fan et al., 2006).

Among the species studied, another interesting association was observed. The greater quantity of gelatinous fibers in variety UnB 201 seemed to be associated with narrower vessels, as a compensation mechanism to drought tolerance. Cassava variety UnB 201 had narrower vessels and more gelatinous fibers than cassava UnB 122. Gelatinous fibers have highly hygroscopic and porous walls with a high cellulose content. These characters are usually associated with water retention (Bailey and Kerr, 1937; Nassar et al., 2010).

The greater quantity of this cellular type in M. fortalezensis is probably an adaptive characteristic. This species is native to dry regions (Caatinga vegetation) (Nassar et al., 
2008), shows high height (ca. $5 \mathrm{~m}$ ), and very slender stem (ca. $10 \mathrm{~cm}$ ) without branches. This type of plant branching and growth make it very susceptible to breakage. Gelatinous fibers may be a mechanism of tension resistance, since they are usually associated with wood tension (Paviani, 1974). Furthermore, they are associated with tolerance to drought (Paviani, 1974; Nassar et al., 2010).

Other important feature found in all plants was the presence of calcium oxalate druses in cortical parenchyma, which are defense against herbivory and expand the use of light in leaf sub-epidermal tissues in shaded enviroments (Molano-Flores, 2001).

This study needs to be complemented by cytogenetic studies and studies with wellknown genetic markers, because they can clarify genetic effects and how much time do they require. This study may provide some evidence of grafting potential in the horizontal transfer of genes and may suggest a very useful tool in cassava production.

\section{ACKNOWLEDGMENTS}

Research supported by the National Council of Scientific Research (CNPq), Brasília. Thanks are due to the Canadian International Development Research Center (IDRC) for establishing the Manihot Living Collection at Universidade de Brasília, DF, Brazil.

\section{REFERENCES}

Bailey IW and Kerr T (1937). The structural variability of the secondary wall as revealed by "lignin" residues. Arnold Arboretum J. 18: 261-272.

Brujin GH and Dharmaputra TS (1974). The mukibat system, a high-yielding method of cassava production in Indonesia. Netherlands J. Agric. Sci. 22: 89-100.

Fan L, Linker R, Gepstein S, Tanimoto E, et al. (2006). Progressive inhibition by water deficit of cell wall extensibility and growth along the elongation zone of maize roots is related to increased lignin metabolism and progressive stellar accumulation of wall phenolics. Plant Physiol. 140: 603-612.

Fassio C, Heath R, Arpaia ML and Castro M (2009). Sap flow in "Hass" avocado trees on two clonal rootstock in relation to xylem anatomy. Sci. Hortic. 120: 8-13.

Hussein LA and MacFarland MJ (1994). Rootstock induced differences in sap flow of "Granny Smith" apple. Hortic. Sci. 29: $1120-1123$

Johansen DA (1940). Plant Microtechnique. McGraw Hill, New York.

Kraus JE and Arduin M (1997). Manual Básico de Métodos em Morfologia Vegetal. Seropédica, Rio de Janeiro.

Liu Y (2006). Historical and modern genetics of plant graft hybridization. Adv. Genet. 56: 101-129.

Luque R, Sousa HC and Kraus JE (1996). Métodos de coloração de Roeser (1972) - modificado - Kropp (1972) visando a substituição do azul de astra por azul de alcião 8GS ou 8GX. Acta Bot. Bras. 10: 199-212.

MacLean RC and Ivemey-Cook WR (1952). Textbook of Practical Botany. 5th edn. Longmans Greenands Co., London.

Mitani N, Matsumoto R, Yoshioka T and Kuniga T (2008). Citrus hybrid seedlings reduce initial time to flower when grafted onto shiikuwasha rootstock. Sci. Hortic. 116: 452-455.

Molano-Flores B (2001). Herbivory and calcium concentrations affect calcium oxalate crystal formation in leaves of sida (Malvaceae). Ann. Bot. 88: 387-391.

Nassar NMA (1981). Interespecific Manihot grafting: a way to maintain wild cassavas, Manihot spp. in living collections. Cienc. Cult. 33: 414-416.

Nassar NMA (2002). Keeping options alive and threat of extinction: a survey of wild cassava survival in its natural habitat. Gene Conserve 1: 1-10.

Nassar NMA (2007). Wild cassava, Manihot spp. to improve the crop. Gene Conserve 6: 387-414.

Nassar NM, Hashimoto DY and Fernandes SD (2008). Wild Manihot species: botanical aspects, geographic distribution and economic value. Genet. Mol. Res. 7: 16-28.

Nassar NM, Abreu LF, Teodoro DA and Graciano-Ribeiro D (2010). Drought tolerant stem anatomy characteristics in Manihot esculenta (Euphorbiaceae) and a wild relative. Genet. Mol. Res. 9: 1023-1031. 
Ohta Y and Chuong PV (1975). Hereditary changes in Capsicum annuum L. I. induced by ordinary grafting. Euphytica 24: $355-368$

Paiva JGA, Fank-de-Carvalho SM, Magalhães MP and Graciano-Ribeiro D (2006). Verniz vitral incolor 500 ${ }^{\circledR}$ : uma alternativa de meio de montagem economicamente viável. Acta Bot. Bras. 20: 257-264.

Paviani TI (1974). Sobre a ocorrência de fibras gelatinosas em Plathymenia reticulata benth. Cienc. Cult. 26: 783-786.

Pellet D and El-Sharkawy MA (1994). Sink-source relations in cassava: effects of reciprocal grafting on yield and leaf photosynthesis. Exp. Agric. 30: 359-367.

Ramanujam T and Ghosh SP (1990). Investigations of source-sink relations in cassava using reciprocal grafting. Exp. Agric. 26: 189-195.

Richter HG and Dallwitz MJ (2009). Commercial Timbers: Descriptions, Illustrations, Identification, and Information Retrieval. In English, French, German, Portuguese, and Spanish. Version: June 25, 2009. Available at [http://deltaintkey.com] 2000. Accessed July 29, 2010.

Rickard JE and Gahan PB (1983). The development of occlusions in cassava (Manihot esculenta Crantz) root xylem vessels. Ann. Bot. 52: 811-821.

Sass JE (1951). Botanical Microtechnique. The Iowa State College Press, Ames.

Schmid PP and Feucht W (1981). Differentiation of sieve tubes in compatible and incompatible Prunus graftings. Sci. Hortic. 15: 349-354.

Solari LI, Johnson S and DeJong TM (2006). Relationship of water status to vegetative growth and leaf gas exchange of peach (Prunus persica) trees on different rootstocks. Tree Physiol. 26: 1333-1341.

Stegemann S and Bock R (2009). Exchange of genetic material between cells in plant tissue grafts Science 324: 649-651.

Taller J, Yagishita N and Hirata Y (1999). Graft-induced variants as a source of novel characteristics in the breeding of pepper (Capsicum annuum L.). Euphytica 108: 73-78.

Wang ZY, Gould KS and Patterson KJ (1994). Comparative root anatomy of five Actinidia species in relation to rootstock effects on kiwifruit flowering. Ann. Bot. 73: 403-413.

Yoshimura K, Masuda A, Kuwano M, Yokota A, et al. (2008). Programmed proteome response for drought avoidance/ tolerance in the root of a C3 xerophyte (wild watermelon) under water deficits. Plant Cell Physiol. 49: 226-241. 